\title{
糖尿病患者の口腔領域の手術後の創傷治療とその背景因子の検討
}

\author{
藤元栄輔・岡部孝一・高塚茂行 \\ 熊谷茂宏・中川清昌・山本悦秀
}

\section{Background factors related to the postoperative wound healing of oral lesions in diabetic patients}

\author{
Eisuke Fujimoto $\cdot$ Koichi Okabe $\cdot$ Sigeyuki Takatsuka \\ Shigehiro Kumagai $・$ Kiyomasa Nakagawa $\cdot$ Etsuhide Yamamoto
}

\begin{abstract}
The purpose of this study was to identify factors affecting postoperative healing in diabetic patients.

During the 8 years from 1984 to 1991, 61 patients with diabetes mellitus were admitted to hospital and underwent oral surgical procedures.

The oral lesions of these patients consisted of 24 odontogenic infections, 18 tumors, 13 cystic lesions, 3 traumas and 3 other lesions. Fifty-four of the patients suffered from not only diabetes mellitus but also from other systemic complications.

All patients were under the care of physicians and well controlled preoperatively; their fasting blood sugar was maintained under $150 \mathrm{mg} / \mathrm{d} l$ and no ketonuria was detected. Poorer postoperative healing was observed in 11 patients. As associated factors, consistent blood sugar control and the duration of surgery were significantly correlated with the healing process.
\end{abstract}

Key words: oral surgical procedure (口腔外科手術), diabetes mellitus (糖尿病), glycohemoglobin $\mathrm{A}_{1 \mathrm{c}}$ (グリコへモグロビン $\mathrm{A}_{1 \mathrm{c}}$ )

緒

言

本邦に扣ける糖尿病患者数は年々増加傾向にあり，平 均寿命の延長ともあいまって, 糖尿病患者の受診機会も 増加している。 また，従来やや避けられがちであった糖 疗病患者の口腔外科手術例も増加している。しかし, 糖 尿病患者は特殊な代謝病態, 特有な毛細血管基底膜肥厚 と主要臟器の器質的・機能的変化を伴っており, 観血的 処置を行う時期や，術前・術中・術後管理には十分な配 慮が必要である．今回当科に入院のう方，各種口腔外科 手術を受けた糖尿病合併症例の術後創傷治療経過を観察 し，術後経過に影響する背景因子についての検討を行っ

金沢大学医学部萪科口腔外科学講座

（主任：山本悦秀教授）

Department of Oral Surgery, School of Medicine, Kanazawa University (Chief: Prof. Etsuhide Yamamoto)

受付日：平成 5 年 1 月 20 日
たので報告する．

\section{対象および研究方法}

1984年 1 月から1991年12月までの 8 年間に，金沢大学 医学部附属病院歯科口腔外科に入院した 1,485 例の入院 診療録を基に検討した．各種口腔外科手術を行った糖尿 病患者について 性差, 年齢, 糖尿病以外の合併症の有 無, 糖尿病の治療期間, 手術時間, 血糖值のコントロー ル状況を重視して術後の治瘉経過を検討した。治瘜経過 異常の発生率の比較検定には， $\chi^{2}$ 検定を用い，条件に応 じて Yates の補正を施行し， $\mathrm{P}<0.05$ を有意差ありとし た.

\section{1. 臨床統計的観察}

1) 対象症例

各年の糖尿病合併患者は，1984年が入院総数 199 例中 
表 1 男女別 - 性別症例数

\begin{tabular}{c|c|c|c}
\hline 年 齿 & 男 性 & 女 性 & 計 \\
\hline $20 \sim 29$ & 0 & 1 & 1 \\
$30 \sim 39$ & 1 & 0 & 1 \\
$40 \sim 49$ & 11 & 7 & 18 \\
$50 \sim 59$ & 9 & 2 & 11 \\
$60 \sim 69$ & 10 & 7 & 17 \\
$70 \sim 79$ & 6 & 5 & 11 \\
$80 \sim 90$ & 2 & 0 & 2 \\
\hline 計 & 39 & 22 & 61 \\
\hline
\end{tabular}

表 2 口腔疾患別患者数

\begin{tabular}{c|c}
\hline 疾患名 & 症 例 数 \\
\hline 炎 症 & 24 \\
腫 瘍 & \\
悪 性 & 13 \\
良 性 & 5 \\
䡛 胞 & 13 \\
外 傷 & 3 \\
その他 & 3 \\
\hline
\end{tabular}

9 例 (約 $4.5 \%), 1985$ 年が 205 例中 6 例(約 $2.9 \%), 1986$ 年が 209 例中 11 例 $($ 約 $5.3 \%$ )，1987年が 210 例中 8 例（約 $3.8 \%$ )，1988年が190例中 4 例（約 $2.1 \%$ )，1989年が 119 例中 5 例 (約 $4.2 \%), 1990$ 年が176例中 9 例 (約 $5.1 \%$ ), 1991年が 177 例中 9 例（約5.1\%）であった，延べ 61 例 中, 異なる疾患で 2 度入院したものが 5 例含まれてい た. 男女別・年齢別分布では，男女比は約 2 対 1 と男性 が多数を占め, 年㱓分布では大多数が 40 歳代以上で, 80 歳代も 2 例含まれていた（表 1 ）.

来院経路は, 当院他科よりの紹介が 7 例, 他病院・医 院よりの紹介が 18 例, 歯科医院よりの紹介が 25 例之紹介 患者が大多数を占めた．直接当科を受診したものは，11 例のみであったが，近年増加傾向にあった。

糖尿病の治療歴は 1 年未満のものが 10 例, 1 年から 5 年が13例, 6 年から10年が 12 例, 11 年から 15 年が 7 例, 16年以上が 8 例であった。 な括，当科術前検査で初めて 糖㽷病が指摘されたものは 1 年末満として集計した.

口腔疾患別患者数をみると, 炎症が 24 例と約 4 割を占 め, つづいて腫瘍が18例, 震胞が13例, 外傷が 3 例, そ の他 3 例であった（表 2 ）。炎症は，歯周炎・歯槽骨炎 が10例と多数を占め, 抜歯を目的とした入院が多かっ た。他の炎症は, 顎骨骨䯣炎 5 例, 歯性上顎洞炎 4 例, 慢性顎下腺炎 3 例，その他 2 例であった。 また，炎症の 急性期に入院した症例は 4 例であった，腫瘍は，悪性腫 瘍が13例，良性腫瘍が 5 例であった。悪性腫瘍 13 例中 3
表 3 糖尿病以外の合併症

\begin{tabular}{l|c}
\hline 疾患名 & 症 例 数 \\
\hline 高血圧症 & 30 \\
心疾患 & 14 \\
肝疾患 & 11 \\
呼吸器疾患 & 6 \\
眼疾患 & 5 \\
腎疾患 & 4 \\
神経系疾患 & 4 \\
その他 & 6 \\
\hline 糖尿病のみ & 7
\end{tabular}

例は, 化学療法, 放射線療法を主体とした治療を行い, 試験切除術のみ施行した. 他の 10 例は化学療法, 放射線 療法とともに外科療法を行っていた.

糖尿病に加えて全身の合併症を有する頻度をみると， ほとんどの患者がなんらかの 合併症を有していた（表 3). すなわら高血圧症は 30 例と約半数に合併し，つづ いて心疾患, 肝疾患, 呼吸器疾患の順であった。 また眼 疾患，腎疾患はそれぞれ 5 例，4 例と少数であった。一 方, 糖尿病以外に合併症を有しない者は 7 例のみであっ た.な括，複数の合併症を有する症例は各疾患に重複し 集計した。

2) 糖尿病患者の術前管理

今回の検討では大多数の者が，すでに一定期間内科医 によって糖尿病治療の管理下にあり, 内科主治医と密接 な連絡を保ち，その助言下に患者管理が行われていた。 術前の糖尿病に対する治療法をみると，食事療法のみの 者が30例, 経口糖尿病薬を服用していた者が20例, イン シュリン療法を受けていた者が11例であった． 約半数が 食事療法のみとされていたが，らち11例はコントロール が不十分で当院内科対診の上，食事制限の再検討が必要 であった。 また経口糖尿病薬を服用していた者，インシ ュリン療法を受けていた者の中にもコントロールの再検 討が必要であった者が 8 例含まれていた。

61例すべて術前に内科医対診し，合同で糖尿病のコン トロールを計り，尿中ケトン陰性，空腹時血糖 (FBS) $150 \mathrm{mg} / \mathrm{d} l$ 以下を術前の目安としてコントロールがなさ れていた。

3 ）術中管理

61例中局所麻酔下の手術は 5 例のみで, 他は麻酔医の 管理下で全身麻酔下に手術施行した。 また手術時間が 4 時間以上を要した症例も 6 例あるが，全例術中に異常は 認められなかった。

4 ) 術後経過

術後は症例に応じて 1 日 1 ないし 6 回血糖值の測定を 行い, 尿糖の測定, 尿中ヶトンの測定を行った。 血糖值 
は 150〜 $200 \mathrm{mg} / \mathrm{d} l$ を目安としてコントロールを行い, 1 日尿糖 $10 \mathrm{~g}$ 以下, 尿中ヶトン陰性を目標として, 必要 に応じてィンシュリン療法を行った。

術後の創傷治癒経過には, 11例に異常を認めた。疾患 別にその内訳をみると, 腫瘍は創縁あるいは再建術に応 用した皮弁の部分壊死を生じた者 3 例と創傷の治痊遅延 3 例, 創部感染を生じた者 1 例で, 炎症は創傷の治瘉遅 延を認めた者が 2 例, 䙶胞は創傷治瘉遅延 1 例と創部感 染 1 例であった。

\section{2. 術後創傷治瘾経過の背景因子の検討}

1）口腔疾患別

口腔疾患別にみると, 術後経過に異常を示した症例の 発生率は腫瘍とそれ以外の疾患との間に統計学的に有意 $(\mathbf{P}<0.025)$ な差を認めた。 そこで各疾患群ごとに背景 因子の検討を行った。な拈，日常の血糖值コントロール の良否は内科医のコメントをもとに，へモグロビン $\mathrm{A}_{1 \mathrm{c}}$ 值 $\left(\mathrm{HbA}_{1 \mathrm{c}}\right.$ 值) $8.0 \%$ 以上を不良, $7.9 \%$ 以下を良好とし て判断した.

（1）悪性腫瘍

試験切除術あるいは小範囲の腫瘍切除術を行った症例 は 3 例で，いずれも良好な治瘉を呈した。顎骨の部分切 除を伴う腫瘍切除術は 3 例に行われ，らち 1 例に創傷の 治癒遅延を認めた。良好な治癒を示した 2 例は，いずれ も手術時間は 1 時間以内で, 日常の血糖值のコントロー ル状態も良好であった。治癒遅延を呈した症例は手術時 間 3 時間20分で, 術前に血糖値の再コントロールを行っ ていた

頸部郭清術を受けた症例は 3 例で， 1 例に治癒遅延を 認めた。良好な治瘉を示した症例の手術時間は 2 時間以 上を要していたが, 日常の血糖值のコントロール状態は 良好であった。治癒遅延例は手術時間は 2 時間以内であ ったが，入院時に糖尿病が発見され術前に血糖值のコン トロールを要した症例であった。

腫瘍切除・頸部郭清・即時再建手術を受けた 4 例で, 2 例に再建術に応用した皮弁の一部壊死を生じ, 1 例に 術後感染を認めた。 4 例とも手術時間は 4 時間以上を要 したが，治瘉良好例は日常の血糖値のコントロール状態 は良好であった，創傷治瘉経過異常例は 1 例は日常の血 糖値のコントロール状態は良好であったが， 2 例は術前 に血糖値のコントロールの再検討を要した症例であっ た。

\section{（2）良性腫瘍}

5 例中 3 例は良好な治癒を呈し, いずれも日常の血糖 值のコントロール状態は良好で, 手術時間は 3 時間以内 であった，創縁の部分壊死を認めた 1 例は, 日常の血糖 值のコントロール状態は良好で, 手術時間は 5 時間以上 を要した症例であった。創傷の治瘉遅延を呈した 1 例 は, 手術時間 1 時間であったが術前に血糖值のコントロ ールの再検討を要した症例であった。
(3) 炎症

抜歯術を行った10例はいずれる手術時間は 2 時間以内 であったが，1例に創傷の治癒遅延がみられた，治癒良 好例は日常の血糖值のコントロール状態も良好であった が，治瘉遅延例は煩部膿瘍を併発していたためか血糖值 のコントロールに乱れが生じており，インシュリンによ る血糖値のコントロールとともに消咨を計り抜歯・膿瘍 切開術を行っていた。

顎骨骨髄炎では 5 例中 3 例が入院時に急性症状を認 め, 血糖值のコントロールには乱れが生じており, イン シュリンによる血糖值のコントロールとともに消炎を計 った後手術施行した。 5 例とも手術時間は 2 時間以内で あったが，急性症状を呈し入院した中の 1 例に創傷の治 疮遅延がみられた。

歯性上顎洞炎, 顎下腺炎などでは 4 例血糖值の再コン トロールを要した症例も含まれていたが，いずれも良好 な治瘉を示した。

(4) 薑胞

桽胞の完全摘出術が 8 例， 口腔内への開空術が 5 例に 行われ, 前者に 2 次感染 1 例, 後者に治癒遅延 1 例を認 めた，完全摘出術例はいずれも手術時間は 2 時間以内 で, 1 例のみ血糖值の再コントロールが必要であった が，創傷治瘉は良好であった。開空術例の手術時間は全 例 1 時間以内で， 4 例に血糖值の再コントロールが必要 であったが， 5ち 1 例に治癒遅延を認めた。

（5）外傷，その他

外傷やその他の疾患群には 1 例日常の血糖値のコント ロールに問題のある症例が含まれ，3時間以上の手術時 間を要した症例も 2 例含まれていたが，いずれも術創は 良好に治瘉した。

また，いずれの疾患群においても年龄, 性別, 糖尿病 以外の合併症の有無, 糖尿病の治療方法, 糖尿病の治療 期間などにはあきらかな差異はみられなかった。

2 ) 手術時間

覀性・良性腫瘍群での検討で，手術時間との関連が窥 える成績であったため, 全症例における手術時間と創傷 治瘉経過の差異を検討した。 1 時間未満の24例中異常経 過を示した症例は 1 例のみであったが， 4 時間以上を要 した症例では 6 例中 4 例に術後経過の異常を認めた（図 1). 手術時間を 3 時間で区切ってみると， 3 時間未満の 42 例中異常経過を示したのは 5 例であるのに対し， 3 時 間以上を要した 9 例中 5 例に異常経過を認め, 統計学的 に有意 $(\mathrm{P}<0.00 .5)$ な差を認めた。

$3 ）$ 日常の血糖値コントロール状況

悪性・良性腫瘍，炎症で術直前のみならず日常の血糖 値のコントロール状態との関連が窺える成績であったた め, 全症例に打けるコントロール状態と創傷治瘉経過の 関連を検討した。コントロール良好群では40例中異常経 過を示した症例は 3 例のみであったが，不良群では21例 


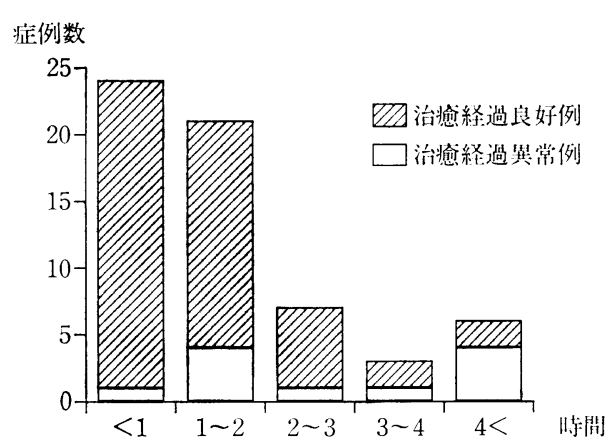

図 1 手術時間別症例数

中 8 例に異常経過を認め, 不良群に打いて統計学的に有 意 $(P<0.005)$ に高い発生率であった（図2）.

\section{考案}

日本に打ける糖尿病有病率は1980年頃には40歳以上で 1〜 5\%であったが，1990年代には約10\%に増加してい る ${ }^{1)}$. 近年の食生活の変化, 人口の老秢化と相まって罹 患者は増加傾向にあり, 特に都市部で罹患者が多く, 糖 尿病は新たな国民病として認識すべき状況である。糖尿 病はインシュリン作用の絶対的あるいは相対的不足によ って引き起こされる代謝障害であり，全身諸臓器に多大 なる影響を与光，種々の合併症を併発する．正常者に比 べて糖疗病患者の歯・口腔疾患罹患率が有意に高いとす る報告 ${ }^{2,3)}$ は多く，時として重篤な感染症をきたすこと もあり ${ }^{4 \sim 7)}$ ，腎疾患，眼疾患などと同様に歯・口腔疾患も 糖疗病合併症の一つとして十分留意すべきと思われる.

\section{1. 糖尿病合併患者の口腔外科手術}

糖尿病患者の易感染性や感染症の重篤化には高血糖が 関与するといわれ，細網内皮系機能の低下，貪食細胞数 の減少, Kupffer 細胞の貪食能の低下, 多核白血球の遊 走能と貪食後の殺菌能の低下がみられる ${ }^{8 \sim 10)}$. それに加 えて, 高血糖に付随する脱水, 電解質異常, ケトアシド ーシスが感染に対する抵抗力を弱めていると考觉られ る $^{11,12)}$. さらに感染が起こるとインシュリン拮抗ホルモ ンの増加, インシュリン分解の促進が起こり, インシュ リン欠乏が増悪し糖尿病がさらに悪化をきたす ${ }^{13)}$. 観血 的処置に際してはこれらの点に十分配慮すべきであり， 血糖值のコントロールとともに感染病巣の除去を計るこ とが肝要と考える。

また糖疗病患者は易感染性であるとともに創傷の治癒 遅延がみられることもあり, 観血処置に際しては外科的 困難症の 1 つして注意が必要である．糖尿病の創傷治 癒遅延は, 細小血管障害による組織の血流の低下や糖・ 蛋白代謝障害による組織の異化六進などが関与するとい われている ${ }^{14 ~ 18)}$ ，近年，西垣 ${ }^{17)}$ はラットを用いた検討か

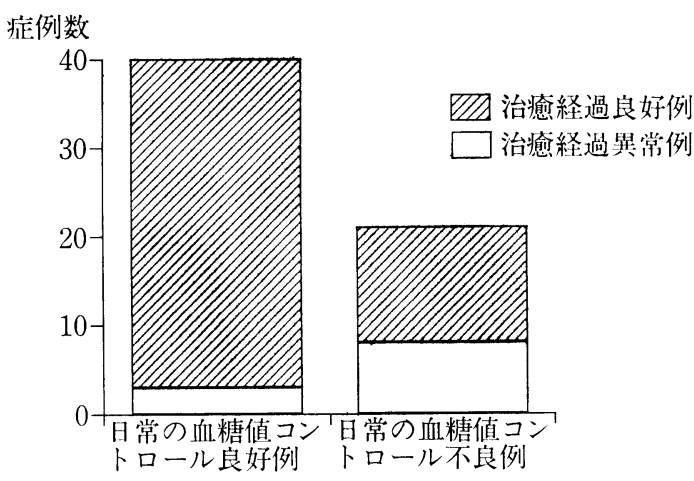

図 2 日常の血糖值コントロール状況別症例数

ら，創傷治瘉遅延はその初期では創傷部の反応性炎症の 弱さと遅延，フィブリン網の形成不全と上皮化完了の遅 れに起因し，さらに線維芽細胞の活性・機能の低下，コ ラーゲン線維の産生と成熟過程の障害が関与すると報告 している. したがって，糖尿病患者の手術に際しては, 順調な術後の治瘾経過を辿っている症例においても, 注 意深い観察が必要と思われる。

糖尿病患者の手術に際しては糖代謝障害の是正と, 主 要臓器の機能障害程度の把握が重要とされている ${ }^{19 \sim 21)}$. 糖尿病患者は, 特異な微小血管障害を基盤とした心葴, 腎臓などの主要臓器の機能不全を伴った症例が多く，高 血圧症, 心電図異常, 腎機能異常が20 30\%の頻度でみら れる ${ }^{11,19)}$ 。これらの臓器障害が糖尿病患者の観血処置の 危険率をより高めている。糖尿病罹患期間が長いほど蔵 器障害の合併率が高く, その程度も重篤化しやすいとい われ，3 年以上の罹病期間を経過しているものでは，糖 㽷病治療の有無に関わらず, それぞれの臓器機能は低下 しているものと考えられる ${ }^{11,19)}$. また赤木ら ${ }^{19)}$ は, 重症 糖尿病患者の術後に肝障害の合併する頻度が高いことか ら, 肝予備力に関する検討の重要性も指摘している。今 回の検討でも61例中54例になんらかの蔵器障害を合併し ており，特に高血圧症は約半数の患者に合併していた。 単に血糖值のコントロールのみに捕らわれず, 患者の全 身状態を把握し，対処することが重要と考えられる。

また術前のコントロールの良否が手術の予後を大きく 左右するといわれ，術前コントロールの目安として空腹 時血糖 $150 \mathrm{mg} / \mathrm{d} l$ 以下, 尿中ヶトン陰性, 尿糖陽性で 1 日 $10 \mathrm{~g}$ 以下とする報告が多い11,12,19 23)，われわれは内科 医とともに空腹時血糖 $150 \mathrm{mg} / \mathrm{d} l$ 以下，尿中ヶトン陰性 を術前の目標としてコントロールし，観血的処置を行っ た. 手術侵襲が大きい場合では，手術を安全に行うため に術前の栄養状態の把握も重要な点と思われる，糖尿病 患者ではインシュリン不足により，もともと肝グリュー ゲン貯蔵量が少なく，脂肪・蛋白質分解が促進されてい る.この異化え進は脂肪酸の過剰生産をきたし，血中の 
ケトン体の出現, アシドーシスを招き, 創傷治瘉の面で もまた術後感染発生の面でも悪影響を与える ${ }^{12)}$.したが って術前に糖質を十分に投与し，グリコーゲンの貯蔵量 を増して扣くことが必要と考えられる。

術中・術後には, 低血糖を予防するために血糖值を $150 \sim 200 \mathrm{mg} / \mathrm{d} l$ とやや高くコントロールしている. 術 後数日間はいわゆる外科的糖尿と呼ばれるカテコールア ミンやグルココルチコイドの分泌が増大し糖新生作用が 克進する状態になるが, 糖尿病患者ではこの外科的糖尿 がより顕著になるといわれて扣り ${ }^{12)}$, 症例に応じて 1 日 $1 \sim 6$ 回の血糖値の測定を行い対応した. また熱型や局 所の状態に留意し, 十分量の抗生剂投与を心がける必要 があるものと考えられた。

\section{2. 術後経過に影響を与える因子}

全例前述のごとく術前・術中・術後管理が行われてい たが，11例には術後経過に異常をきたした．糖尿病合併 患者の術後経過に影響を与える因子として, 術前の血糖 值のコントロールや処置侵襲の大きさ, 日常の糖尿病治 療の適否, 治療期間, 糖尿病のタイプなどは重要な点で あるといわれている ${ }^{12,23)}$. 今回, これらの点に特に注意 し, 各症例の背景因子の検討を行った. この中で術前の 血糖值のコントロールは前述のごとく内科医とともに行 って扣り, 糖尿病のタイプはほとんどの症例がインシュ リン非依存型 (non-insulin dependent, NIDDM) であ ったため検討項目から除外した.

手術侵襲の大きさが術後経過に関与することは従来よ り示唆されている。 また酒向 ${ }^{18)}$ はマウスを用いた検討か ら, 血糖値コントロールの重要性と, 手術侵襲の少ない 術式の選択を推奨している. 今回の検討では, 手術侵襲 の大きさを表す指標として手術時間を採用したが，3時 間を越える症例の術後経過に異常を生じる率が有意に高 かった. 糖尿病患者では臓器組織が脆弱化している傾向 があり, 愛護的かつ手早い手術操作が 必要と考えられ た.

近年, 糖尿病コントロールの指標として, フルクトサ ミンと $\mathrm{HbA}_{1 \mathrm{c}}$ 值がしばしば用いられる24 26). 前者は比 較的短期間の, 後者は過去 $1 \sim 2$ か月の血糖のコントロ ール状態をよく反映するとされている，直ら ${ }^{24)}$ は糖尿病 性網膜症が平均 $\mathrm{FBS}$ よりも平均 $\mathrm{HbA}_{1 \mathrm{c}}$ によりよく一 致することから，一定期間の血糖值制御状態を反映する $\mathrm{HbA}_{1 \mathrm{c}}$ を指標として推奖している. $\mathrm{HbA}_{1 \mathrm{c}}$ 值の正常值 は 4 〜 6\%゙あるが, 高㱓者ではやや高めに目標を設定 される場合もあり ${ }^{25)}$, われわれは日常の血糖值のコン トロール状態の判定を内科医のコメントを基にして, $\mathrm{HbA}_{1 \mathrm{c}} 8.0 \%$ 一応の基準として判断した ${ }^{27)}$. その結 果, 日常の血糖値のコントロール状態の不良例では良好 例に対して有意に術後経過に異常を生じる率が高く, 術 直前のみならず日常の血糖值のコントロール状態が重要 とする成績であった。 すなわち, 糖尿病に伴う器質的な
変化を防ぐよう努めることが, 各種蔵器障害の発症防止 とともに創傷治瘉にも好影響を与えるものと考えられ た.

手術対象となった口腔疾患別にみると，腫瘍は術後経 過に異常をさたす率が他の疾患群に比べ有意に高い成績 であったが，これは手術侵襲の大きさによる差異と考え られる．腫瘍の術後経過異常例 7 例中, 各種笳皮弁を応 用した再建手術や, 頸部郭清術などで 3 時間以上を要し た症例が 5 例含まれ， 口腔疾患そのものが関与している とはいい難いものと思われた。 また今回の検討では, 糖 尿病の治療期間, 糖尿病の治療法等にはあさらかな差異 はみられなかったが, 糖尿病患者の外科処置に際しては 残意すべき因子と考える。

以上述べてきたように, 糖尿病合併患者の手術に際し ては従来より推奖されている適切な術前コントロール, 全身状態の把握とともに，手術侵襲に対する配慮や日常 の血糖值コントロール状態 $\left(\mathrm{HbA}_{1 \mathrm{c}}\right.$ 值) に留意すべきで ある.われわれは糖尿病合併患者の処置に際しては内科 対診の上，血糖值を十分コントロールした後に臨むこと としている.このため処置までに時間を要した症例もあ ったが，緊急手術などを除さ，時間的にも余裕をみて対 処するべきであると考えている.

\section{結語}

1984年 1 月から1991年12月までの 8 年間に, 金沢大学 医学部附属病院歯科口腔外科に入院の上, 各種口腔外科 手術を行った糖尿病合併患者61例について検討した。

1. 性差は約 2 対 1 と男性が多く，年齢別では 40 歳以 上が大多数を占めた。腔疾患別では, 炎症 24 例, 腫瘍 18例, 霬胞13例, 外傷 3 例, その他 3 例の順であった.

2. 全例尿中ヶトン陰性, 空腹時血糖(FBS) $150 \mathrm{mg} / \mathrm{d} l$ 以下を目安として術前にコントロールしたが, 11例の術 後治癒経過に異常を認めた。

3. 腫瘍と他の疾患, 手術時間 3 時間未満の症例と 3 時間以上の症例, 日常の血糖値コントロール状態 $\left(\mathrm{HbA}_{1 \mathrm{c}}\right.$ 値) の良好例と不良例との間に統計学的に有意な差を認 めた，糖尿病合併患者の手術に際しては，手術侵襲に対 する配慮や日常の血糖値コントロール状態に留意すべき であると考えられた。

本報告の要旨は日本・米国合同学術会議（平成 4 年 9 月，ハワイ州，アメリカ合衅国）に执いて発表した.

\section{引用文 献}

1）葛谷 健, 伊藤千賀子, 他：日本人の糖尿病有 病率と発症率一日本糖尿病学会疫学データ委員 会報告一。糖尿病 35：173-194 1992. 
2) Tenovus, J., Alanen, P., et al.: Oral health of patients with insulin-dependent diabetes mellitus. Scand J Dent Res 9: 91-96 1986.

3）柴崎貞二：糖尿病患者に括ける歯・口腔疾患と その予防。坂本信夫, 兼子俊男監修; 糖尿病力 レントレビュー1990。第 1 版, 医歯薬出版, 東 京, 1990, 269-292頁.

4）横田光正, 大阪博伸, 他：糖尿病患者にみられ た重症歯性感染症の 2 症例. 口科誌 $36 ： 197$ 2021987.

5）斎藤健一, 森 紀美江, 他：糖尿病患者にみら れた難治性感染症の一治験例。菌薬療法 9: 138-142 1990.

6) 服部康治, 久保田英朗, 他 : 糖尿病に発生した 重篤な歯性感染症の3 例. 日口外誌 37 ：5245331991.

7) 水野有功, 並川有隣, 他 : 糖尿病患者にみられ た智歯周囲炎に継発した側頭部後頭部膿瘍の 1 例. 日口外誌 37：1995-1999 1991.

8) Repine, J.E., Clawson, C.Z., et al.: Bactericidal function of neutrophils from patients with acute bacterial infections and diabetics. J Infect Dis 142: 869-875 1980.

9）平田幸正, 清水喜八郎：糖尿病患者の感染症. Diabetes J 14: 7-14 1986.

10）中畑 久, 平井裕一, 他: インスリン依存性糖 尿病 (IDDM) 患者多形核白血球食食, 殺菌能 の検討一特に血糖コントロール状態との関連に ついて一。糖尿病 34: 7-13 1991.

11）玉熊正悦, 望月英隆 : 糖尿病患者の手術をめぐ る問題。医学のあゆみ 113: 798-804 1980.

12）若林 剛, 相川直樹：糖尿病と外科手術. 赤沼 安夫編集; 糖尿病, 南江堂, 東京, 1988, 95105賁.

13）前沢秀憲：内科シリーズ. No. 3 糖尿病のすべ て。第 1 版, 南江堂, 東京, 1973，541-547頁.

14）橋本 幸：アロキサン糖尿病ラットの拔歯創治 癒過程に関与る実験的研究. 口病誌 30 : 3073281963.
15）千葉英輔：Alloxan 糖尿病ラットの血糖值別に よる拔歯創治瘾経過に関する実験的研究. 歯科 学報 68: 1471-1491 1968.

16) Prakash, A., Pandit, M., et al.: Studies in wound healing in experimental diabetes. Int Surg 59: 25-28 1974.

17）西垣篤正：ストレプトゾトシン誘発糖尿病ラッ 卜の皮膚一次䋖合創の治瘾過程に関する実験的 研究. 歯科学報 89: 793-815 1989 .

18）酒向誠：糖尿病に扣ける口蓋粘膜の創偒治療 に関する実験的研究. 日口外誌 $37: 763-778$ 1991.

19）赤木正信, 前野正伸, 他 : 糖尿病患者の評価と 手術適応。臨外 41：287-294 1986.

20）冲永功太, 宮沢幸久, 他: 糖尿病患者の手術. 医学のあゆみ 139: 812-814 1986.

21）小倉嘉文, 田矢功司, 他：糖尿病; 合併症の評 価と術前 - 術後の輸液計画の実際, 消化器外科 9: 1095-1099 1986.

22) Marble, A., Krall, L.P., et al.: Oral hypoglycemic agents. Krall, L.P.; Joslin's diabetes mellitus, 12th ed, Lea \& Febiger, Philadelphia, 1985, p 412-452.

23）中野芳周, 茂木克俊, 他: 糖尿病患者の術前 ントロールと術後経過について. 口科誌 30 : 300-305 1981.

24）直 克則, 山崎義光, 他 : 糖尿病性綱膜症進展 阻止のための Glycemic Threshold一外来患者 に打ける Retrospectiveな検討一。糖尿病 32 : 307-312 1989.

25）島 健二：老年者の糖尿病. 赤沼安夫編集; 糖 尿病, 南江堂, 東京, 1988, 127-132頁.

26）瀬野倫代, 中崎利彦, 他：糖代謝異常にお㚈る スクリーニング 指標としての fructosamine の 有用性と限界について。糖尿病 32: 653-657 1990.

27) 藤元栄輔, 野尻孝司, 他: 糖尿病患者の各種口 腔外科手術に関する検 討. 口科誌 39: 1-6 1990. 